\title{
Multiple Indicators of Wastewater Contamination to Shellfish Farms Near a Tidal River
}

\author{
Ashley Frith ${ }^{1,2}$. Julian Henseler ${ }^{3} \cdot$ Shahrzad Badri $^{4} \cdot$ Kevin R. Calci $^{5} \cdot$ Alexandra Stenson $^{1} \cdot$ Ruth H. Carmichael ${ }^{1,2}$
}

Received: 29 April 2021 / Revised: 17 November 2021 / Accepted: 19 November 2021 / Published online: 3 December 2021

(c) The Author(s) 2021

\begin{abstract}
Wastewater contamination threatens the shellfish aquaculture industry by posing risks to public health. Multiple indicators of wastewater contamination, including fecal coliforms (fc), male-specific coliphage (MSC), dissolved nutrients, stable isotope ratios, and artificial sweeteners were analyzed to determine possible sources of wastewater to local shellfish farms. Samples were collected at a wastewater treatment plant outfall (WTPO), nonpoint residential, and agricultural areas of a tidal river, and tidal creek inflows adjacent to farms. To capture seasonal variation, we sampled under warm and cold, and wet and dry conditions. Fc ranged $<5-5250 \mathrm{CFU} 100 \mathrm{~mL}^{-1}, \mathrm{NH}_{4}{ }^{+}$concentrations ranged up to $9.58 \mu \mathrm{M}$, and $\delta^{15} \mathrm{~N}$ ranged 1.4-7.8\%o across all sites and time periods. $\mathrm{Fc}$ and $\mathrm{NH}_{4}{ }^{+}$were higher, and $\delta^{15} \mathrm{~N}$ was lower in the cold wet period and near residential and agricultural areas. Acesulfame and sucralose concentrations ranged $0.004-0.05 \mu \mathrm{g} \mathrm{L}-1$ and up to $>0.8 \mu \mathrm{g} \mathrm{L}^{-1}$, respectively, and did not correlate with other indicators but tended to be higher in residential areas and at the WTPO, supporting their value in differentiating human sewage from other sources. Shoreline disturbance during septic system upgrades may have inadvertently contributed bacterial indicators to shellfish farms. Overall, indicator source dominance depended on environmental conditions, with WTPO and residential sources conveying human-specific indicators to farms year-round, while agricultural and industrial sites contributed additional fc during cold wet periods. The use of multiple indicators will aid managers to detect and define wastewater sources, identify targets for monitoring or remediation, and manage shellfish areas in estuaries with a mosaic of land-derived wastewater sources.
\end{abstract}

Keywords Water quality $\cdot$ Fecal coliforms $\cdot$ Ammonium $\cdot$ Stable isotopes $\cdot$ Acesulfame $\cdot$ Sucralose

\section{Introduction}

Shellfish aquaculture is vulnerable to wastewater inputs that convey human pathogens to receiving waters because shellfish can accumulate pathogens in tissues as they filter feed (Rippey 1994; Burkhardt and Calci 2000). The sanitary quality of commercially harvested shellfish is protected through water quality testing, with shellfish harvest restrictions imposed when conditions have potential to expose shellfish growing areas to fecal pollution (Rees et al. 2010; NSSP 2019). Aquaculture is the fastest-growing food production sector, worth an estimated US \$232 billion in 2016 and employing more than 19 million people worldwide (FAO 2018). Of this total value, mollusks, including bivalve shellfish, represented US $\$ 29.2$ billion (FAO 2018). Hence, wastewater contamination can pose significant health risks and cause economic losses in coastal communities (Evans et al. 2016).

Successful management of wastewater contamination relies on understanding the sources of wastewater to the 
system. Established metrics to assess water quality and wastewater sources include bacterial and viral indicators, nutrient concentrations, and stable isotope ratios (e.g., McClelland et al. 1997; Armon and Kott 1996; Cloern et al. 2016). Fecal coliforms (fc) and Escherichia coli are bacterial indicators of sanitary quality used in the U.S. and European Union, respectively, to classify shellfish harvest areas (National Research Council 2004; Rees et al. 2010). Male-specific coliphage (MSC) is a viral indicator of human-derived wastewater that is more similar to human enteric viruses than fc (Hilton and Stotzky 1973; DeBartolomeis and Cabelli 1991; Calci et al. 1998). Dissolved nutrients provide information about the presence of wastewater sources to a given location because wastewater typically conveys different forms and concentrations of dissolved inorganic nitrogen (DIN) depending on source (Valiela et al. 1992, 2000; Tucker et al. 1999). Stable isotope ratios $\left(\delta^{13} \mathrm{C}, \delta^{15} \mathrm{~N}\right)$ can distinguish marine from terrestrial particulate organic matter and processed from raw sewage-derived particles, respectively. Specifically, $\delta^{13} \mathrm{C}$ tends to be lower in land-derived compared to marine sources, and $\delta^{15} \mathrm{~N}$ tends to be lower in raw, unprocessed sewage compared to septic and processed wastewater sources (e.g., McClelland et al. 1997; Rogers 1999; Tucker et al. 1999; Fry 2006; Daskin et al. 2008; Darrow et al. 2016). Individually, these water quality indicators provide some evidence of the presence of wastewater and associated microbes of human concern, but they may have greater potential for source identification when used in combination (Griffin et al. 2001; National Research Council 2004; Biancani et al. 2012; Darrow et al. 2016; James et al. 2016).

Analysis of artificial sweetener concentrations has emerged more recently as a method to better trace humanspecific wastewater sources. Artificial sweeteners can enter the environment after being excreted in urine or feces (Oppenheimer et al. 2011; Lange et al. 2012; Popkin and Hawkes 2016). The presence of artificial sweeteners in a water sample is suggestive of human wastewater because these compounds are not found in nature and are only rarely found in commonly used fertilizers or livestock feed (Hof 2000). Artificial sweeteners do not readily adsorb to soils or organic solids, are slow to degrade in the environment, and are only appreciably removed by advanced wastewater treatment practices (Mawhinney et al. 2011; Oppenheimer et al. 2011; Tran et al. 2014; James et al. 2016). Acesulfame (ACE) and sucralose (SUC) are particularly promising wastewater indicators because they are two of the most commonly consumed artificial sweeteners globally, resulting in concentrations in aquatic environments that exceed those of most other anthropogenic compounds (e.g., medication, personal care products; Loos et al. 2009; Mead et al. 2009; Scheurer et al. 2009; Ordóñez et al. 2012). Accordingly, SUC and ACE have been detected in groundwater, surface water, and wastewater treatment plant effluent (Mawhinney et al. 2011; Oppenheimer et al. 2011; McCance et al. 2018). Although not much is known about artificial sweeteners in the environment, their presence in combination with traditional indicators could help differentiate human from agricultural and wildlife influences.

In this study, we used a combination of traditional (fc, MSC, dissolved nutrients, $\delta^{13} \mathrm{C}, \delta^{15} \mathrm{~N}$ ) and emerging (ACE and SUC) indicators to detect wastewater contributions to shellfish farms in eastern Mississippi Sound on the northern Gulf of Mexico. To link indicator concentrations to potential land-derived wastewater sources, samples were collected at a wastewater treatment plant outfall (WTPO), along the shoreline of the West Fowl River system and tidal creeks, and at an industrial site upstream from the shellfish farms. Collection focused on spatial differences, but samples were also collected under wet and dry conditions during warm and cold periods to test how these conditions may affect wastewater source contributions. To determine if periods of high fc loads could be related to known shoreline activities to help distinguish sources of wastewater to the system, we combined results from this study with a long-term monitoring dataset to enable comparison of historical patterns. We developed a traffic-light icon display to guide end-users in applying our multiple-indicator approach to management. These data provide new information and an empirical case study that demonstrate how multiple indicators can be used to enhance detection and identification of wastewater sources, a first step to manage and remediate wastewater inputs to shellfish growing areas.

\section{Methods}

\section{Study Site and Management Context}

Mirroring trends in global aquaculture, shellfish farming has grown in popularity along the northern Gulf of Mexico coast. In coastal Alabama, shellfish farming began in 2012 and by 2019 comprised 21 farms, valued at approximately US \$1.4 million (Grice and Walton 2020). To protect consumer health, and following US national standards, the Alabama Department of Public Health (ADPH) routinely closes shellfish areas, including shellfish farms, to harvest in response to high microbial indicator concentrations. The river stage (water height above the riverbed) of the Mobile River is often used as a proxy for elevated microbial concentrations, where river stage of $8.0 \mathrm{ft}$ will trigger a shellfish area closure (Byrd et al. 2012). Due to microbial indicator inputs from unknown sources during 2016, a major shellfish farming area in Fowl River Bay (Fig. 1) was reclassified from conditionally approved (closed to harvest during predictable periods of risk) to conditionally restricted (shellfish cannot be directly marketed and must be relayed 


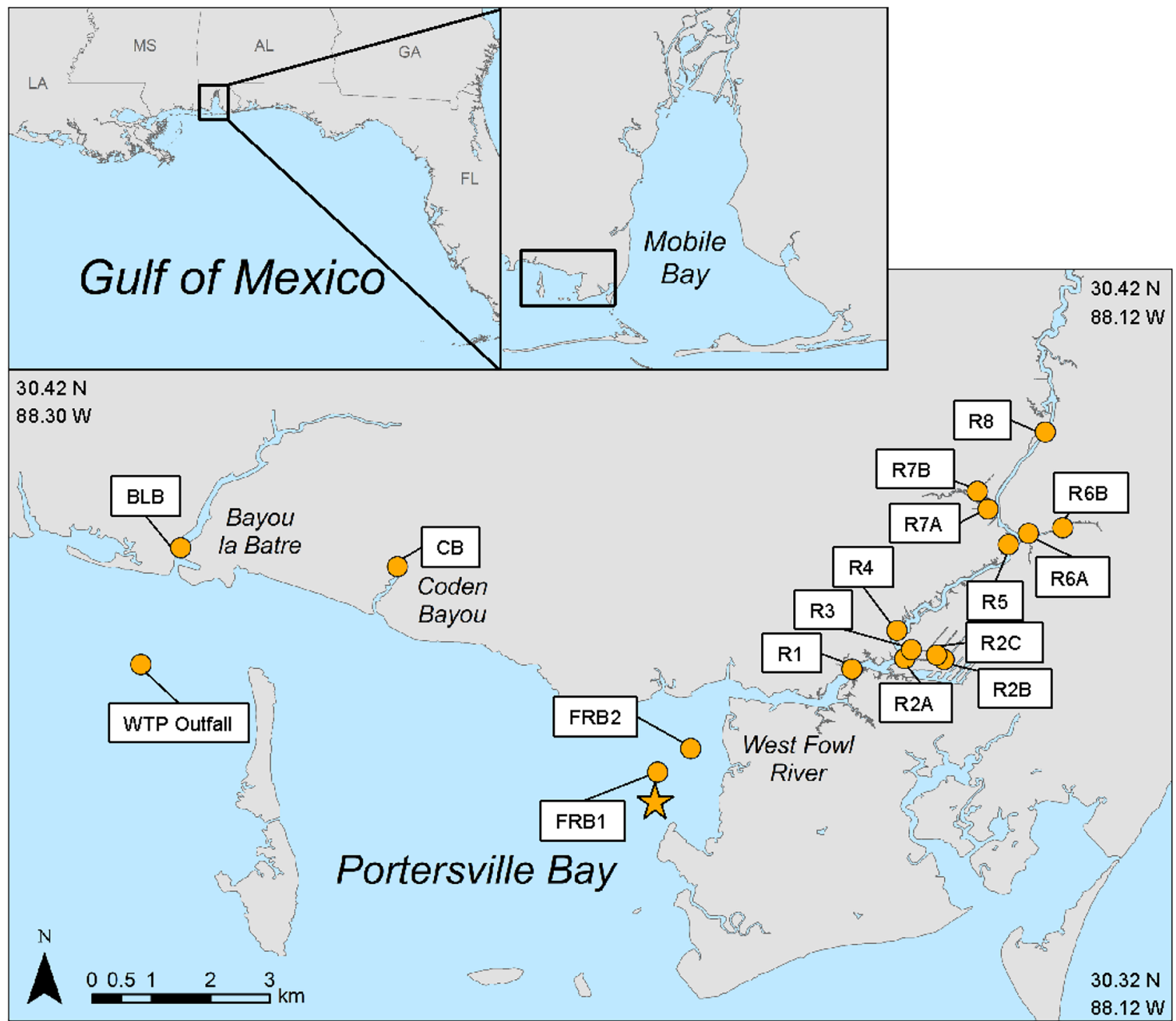

Fig. 1 Sampling locations in Portersville Bay, AL in the northern Gulf of Mexico. Site abbreviations: wastewater treatment plant outfall (WTP Outfall), Bayou la Batre (BLB), Coden Bayou (CB), Fowl

to an approved area for decontamination prior to harvest if conditions allow, otherwise prohibited; NSSP 2019). This change in classification was a major concern to local shellfish farmers because it required additional time-intensive and financially costly steps to make oysters commercially available (Byrd et al. 2012; Grice and Walton 2020).

The Fowl River Bay area is located to the west of Mobile Bay and joins Portersville Bay in eastern Mississippi Sound, Alabama. The area is potentially influenced by water from the Bayou la Batre wastewater treatment plant (WTP), Bayou la Batre bayou (BLB), and Coden bayou to the west, and West Fowl River (WFR) to the northeast. Each of the bays, bayous and the river receive multiple undefined point- and non-point potential
River Bay (FRB), West Fowl River (R). The star represents the sampling site used by the Alabama Department of Public Health in the historical data set

wastewater sources including at least stormwater runoff, livestock agriculture, and septic systems from the adjacent watershed (Mobile Bay National Estuary Program 2019). The Bayou la Batre WTP is a secondary treatment facility that operates under relatively low-flow conditions $\left(\sim 1\right.$ million gallons day ${ }^{-1}$ ) and uses UV disinfection as the final step to remove bacterial and viral indicators of human waste. Based on hydrodynamic modeling and dyeflow studies, the WTP outfall into the Portersville Bay area is expected to be sufficiently diluted under normal operating conditions to not pose a threat to shellfish farms in the area (FDA 2014; Ao 2018; ADEM 2019). The farms are predicted to be affected under higher WTP flow conditions (FDA 2014), as may occur during periods of heavy 
rainfall and discharge. These high discharge conditions are common during colder periods in the study area, along the north-central Gulf of Mexico coast (Dzwonkowski et al. 2011). The potential pathogen contributions from other sources are poorly understood, prompting demand for data to inform management options.

\section{Sampling Scheme}

To capture a range of spatial and temporal variation in indicator concentrations, we sampled water at existing shellfish farms (Fig. 1, FRB2) and at nearby potential wastewater source locations from July 2017 to February 2018. Potential source sites spanned the length of West Fowl River (WFR, $n=17$ ), including areas of known residential (R1, R2A, R2B, R2C, R7A, R7B) and agricultural (R6A, R6B) use; major tributary junctions with potential industrial inputs at Coden Bayou (CB) and Bayou la Batre bayou (BLB); and the Bayou la Batre Wastewater Treatment Plant outfall (WTPO). Sites were sampled on 3 to 5 days during the July to February period, targeting seasonal extremes (i.e., warm/cold based on water temperature $>/<20^{\circ} \mathrm{C}$, and wet/ dry based on mean river discharge $>/<1.8 \mathrm{~m}^{3} \mathrm{~s}^{-1}$ ) for our region in the northern Gulf of Mexico. Samples were collected at outgoing slack or falling tides to best isolate contributions, to the extent possible, from each source before mixing or tidal dilution. All samples for a given month were collected on the same day. At each site, a 500-mL surface water grab sample was collected $0.1 \mathrm{~m}$ below the surface in a sterile Nalgene bottle for microbial indicator analyses. For nutrient, stable isotope, and artificial sweetener analyses, two $1 \mathrm{~L}$ mid-water-column samples were collected using a horizontal water sampler and pre-filtered through 200- $\mu \mathrm{m}$ mesh into acid-washed Nalgene bottles. All bottles were stored upright in ice until processing, within $24 \mathrm{~h}$.

To relate indicator concentrations to environmental conditions at the time of water sampling, a handheld YSI Pro 2030 was used to measure water temperature, salinity, and dissolved oxygen at $0.1 \mathrm{~m}$ below the water surface and $0.1 \mathrm{~m}$ above the sediment. Data also were compiled for rainfall and wind direction because these factors can affect water level that is used to predict fc (Byrd et al. 2012) and could be used to test this relationship in our empirical results. Rainfall was calculated as the sum of precipitation over 3 days prior to sampling, and wind direction for the day of sampling was calculated as the mean of all wind direction vectors over the day, with both variables measured at Cedar Point (ARCOS 2020).

\section{Microbial Analyses}

An aliquot ( $1 \mathrm{~mL}$ and $10 \mathrm{~mL})$ of each water sample was filtered through sterile $0.45-\mu \mathrm{m}$ mixed cellulose esters filters
(EZ-Pak®) using a UV-sterilized vacuum filtration system to capture fecal coliforms (fc). Filters were placed on mTEC (Acumedia ${ }^{\circledR}$ ) media plates and incubated at $35^{\circ} \mathrm{C}$ for $2 \mathrm{~h}$ then at $44.5^{\circ} \mathrm{C}$ for 18 to $24 \mathrm{~h}$, after which time yellow, yellow-brown, or yellow-green coliform forming units (CFU) were counted. A double-agar-overlay method described by Cabelli (1990) was used to quantify malespecific coliphage (MSC), where $2.5 \mathrm{~mL}$ of each water sample were added to soft agar tubes (tryptone, dextrose, $\mathrm{NaCl}$, Difco ${ }^{\mathrm{TM}}$ agar, $1 \mathrm{M} \mathrm{CaCl}_{2}$ ) along with $0.2 \mathrm{~mL}$ of the host strain (E. coli Famp) grown in tryptone in quadruplicate (total sample: $10 \mathrm{~mL}$ ). Tubes were mixed and plated on Famp media plates (tryptone, dextrose, $\mathrm{NaCl}$, Difco ${ }^{\mathrm{TM}}$ agar) and incubated for $24( \pm 2) \mathrm{h}$ at $35{ }^{\circ} \mathrm{C}$ before viral plaque-forming units (PFU) were counted.

\section{Nutrient and Stable Isotope Analyses}

For nutrient and stable isotope analyses, water samples were vacuum-filtered through pre-ashed $0.7-\mu \mathrm{m}$ glass fiber filters to collect particulate matter. Filtrate was reserved in acid-washed bottles and stored at $-20{ }^{\circ} \mathrm{C}$ for nutrient and artificial sweetener analysis. Filtrate was analyzed on a Skalar San + Autoanalyzer for $\mathrm{NO}_{3}{ }^{-}+\mathrm{NO}_{2}{ }^{-}, \mathrm{NO}_{2}{ }^{-}$, $\mathrm{NH}_{4}{ }^{+}, \mathrm{PO}_{4}{ }^{3-}$, and total dissolved nitrogen (TDN), following established EPA colorimetric methods (USEPA 1978, 1993a, b, c) as described by Strickland and Parsons (1972). Briefly, $\mathrm{NO}_{3}{ }^{-}+\mathrm{NO}_{2}{ }^{-}$was measured after coppercadmium reduction to $\mathrm{NO}_{2}{ }^{-}$, and $\mathrm{NO}_{2}{ }^{-}$was subtracted from the $\mathrm{NO}_{3}{ }^{-}+\mathrm{NO}_{2}{ }^{-}$complex (Strickland and Parsons 1972; USEPA 1993c). $\mathrm{NH}_{4}{ }^{+}$and TDN were measured using alkaline phenol and hypochlorite or persulfate oxidation methods, respectively (Strickland and Parsons 1972; USEPA 1993a, b). $\mathrm{PO}_{4}{ }^{3-}$ was measured by complexation with ascorbic acid and ammonium molybdate (Strickland and Parsons 1972; USEPA 1978).

Filters were dried to a constant weight at $60{ }^{\circ} \mathrm{C}$ and packed in tin capsules before sending to the UC Davis Stable Isotope Facility for $\delta^{13} \mathrm{C}$ and $\delta^{15} \mathrm{~N}$ analysis by isotope ratio mass spectrometry using an Elementar Vario EL Cube or Micro Cube elemental analyzer (Elementar Analysensysteme GmbH, Hanau, Germany) interfaced to either an Isoprime VisION IRMS (Elementar UK Ltd, Cheadle, UK) or a PDZ Europa 20-20 isotope ratio mass spectrometer (Sercon Ltd., Cheshire, UK). At least two replicate filters were analyzed for each site and sampling date. As internal controls, blank filters and tins were analyzed along with randomly chosen pseudoreplicate samples (two filters from the same water sample), representing $\sim 10 \%$ of the total sample number to confirm reproducibility, which was $0.16 \%$ or $\delta^{13} \mathrm{C}$ and $0.17 \%$ for $\delta^{15} \mathrm{~N}$, within the facility's long-term standard deviation of $<0.2 \%$ ofor $\delta^{13} \mathrm{C}$ and $0.3 \%$ o for $\delta^{15} \mathrm{~N}$. 


\section{Artificial Sweetener Analyses}

To evaluate the use of artificial sweeteners as an additional water quality indicator, a subset of samples $(n=20)$ was analyzed for acesulfame (ACE) and sucralose (SUC) concentration. Samples for sweetener analyses were selected after other analyses had been completed, based on the availability of adequate liquid (at least $100 \mathrm{~mL}$ ) for analysis, targeting a range of fc results among the potential wastewater sources. Samples were stratified so that one to four semi-replicate samples were analyzed, depending on the volume of available sample. Samples were considered semi-replicates if they were collected in the same location and on the same day, but not necessarily in the same bottle (e.g., $n=4$, when 2 samples were available per bottle for the 2 bottles collected per site). After having been put through the solid-phase extraction method and reconstituted in a minimal volume of solvent (as described below), each semi-replicate was split into two duplicate samples for analysis.

Adapting methods by Scheurer et al. (2009) and Ordóñez et al. (2012), $50 \mathrm{~mL}$ of each sample were acidulated with $50 \mu \mathrm{L}$ formic acid (99\%, for analysis, ACROS Organics). Acesulfame-d $\mathrm{d}_{4}$ (ACE-D4) and sucralose-d 6 (SUC-D6) (Toronto Research Chemicals, Canada) were added as internal standards. Samples were then pre-concentrated through solid-phase extraction (SPE) through Waters Oasis hydrophilic-lipophilic blend cartridges (200 mg, $6 \mathrm{~mL})$. Alongside each assay of five samples, one method blank consisting of deionized (18 $\mathrm{M} \Omega$ ) water (ultrapure water; UPW), formic acid, and internal standards was analyzed. Additional method-control samples taken through the entire method consisted of $0,8,16,32,64$, and $113 \mu \mathrm{L} \mathrm{L}^{-1}$ of ACE or SUC plus internal standards, formic acid, and $4.6 \mathrm{~g} \mathrm{~L}^{-1}$ Suwannee River Natural Organic Matter (NOM). NOM's role is to simulate organic matrix effects in samples. The first method-control sample, containing $0 \mu \mathrm{L} \mathrm{L}^{-1}$ of ACE or SUC, served as the NOM-containing method blank. For all analyzed samples, the method blank and the NOMcontaining method blank indicated no contamination and the calculated concentration of the method-controls at each concentration matched the known concentration.

Following SPE, samples eluted in $9 \mathrm{~mL}$ of LCMS or Optima grade methanol $(\mathrm{MeOH})$ were dried on a Labconco CentriVap evaporator at $30^{\circ} \mathrm{C}$ and reconstituted in $100 \mu \mathrm{L}$ of $5 \mathrm{mM}$ ammonium formate $(\mathrm{pH}$ 5.9-6.1). Each sample was split into two separate autosampler vials for subsequent (duplicate) analysis. Five microliters of each sample, method-control, blank, calibration standard, and calibration control (samples of known amounts of analyte plus NOM $\left.\left(0.092 \mathrm{~g} \mathrm{~L}^{-1}\right)\right)$ were separated on a Phenomenex Kinetex C18 column $(100 \times 3 \mathrm{~mm}, 2.6 \mu \mathrm{m})$ using a Thermo Fisher Scientific Accela 600 pump at a flow rate of $350 \mu \mathrm{L} \mathrm{min}^{-1}$. The gradient was developed with steps between ACE and
SUC elution to reduce matrix complexity and improve resolution, including removal of major interferants (e.g., the bulk of NOM) from the analytes and from the instrument. Samples were initially separated with 5\% MeOH: 95\% ammonium formate. After ACE eluted (at $0.6 \mathrm{~min}$ ), ammonium formate was replaced with unbuffered UPW water, which improved signal-to-noise ratios for the remaining analytes. $\mathrm{MeOH}$ was then gradually increased from 5 to $14 \%$ for the first $2.2 \mathrm{~min}$ and held at $14 \%$ for $2.8 \mathrm{~min}$ before ramping up to $20 \%$ between 5 and $7.5 \mathrm{~min}$. To clean the column, the mobile phase was ramped to $90 \% \mathrm{MeOH}$ from 7.8 to $8 \mathrm{~min}$ and held for an additional $4 \mathrm{~min}$. A Thermo Fisher Scientific LTQ Velos ion trap was used for mass analysis. All analytes were fragmented at $35 \%$ collision energy; peak heights of the following fragment ions were used for quantification: $\mathrm{ACE}-m / z=82$, ACE-D $4-m / z=86$, SUC $-m / z=359$, and SUC-D6 $-m / z=365$.

\section{Data Analyses}

Sampling periods were stratified based on temperature and the combination of discharge and rainfall conditions to allow comparison between environmental conditions and wastewater indicators (Table 1). Sampling dates were classified as "warm" or "cold" based on the average surface water temperature of all sites, using $20{ }^{\circ} \mathrm{C}$ as the threshold point ("warm" and "cold" sampling periods differed, t-test: $\left.F_{1,60}=193.8, p<0.001\right)$. Dates were additionally classified as "wet" or "dry" based on the average Fowl River discharge (USGS station 2,471,078) for two weeks prior to sampling, using $1.8 \mathrm{~m}^{3} \mathrm{~s}^{-1}$ as the threshold point ("wet" and "dry" sampling periods differed, $t$-test: $\left.F_{1,2880}=50.21, p<0.001\right)$. For reference, the median Fowl River discharge from February 2017 to March 2018 was $1.0 \mathrm{~m}^{3} \mathrm{~s}^{-1}$, with max flow periods above $30 \mathrm{~m}^{3} \mathrm{~s}^{-1}$ (waterdata.usgs.gov). Error was calculated as standard error of the mean.

To test for differences among sampling periods, environmental, microbial, nutrient, and stable isotope indicator data were analyzed by ANOVA or Kruskal-Wallis tests, followed by Tukey or Dunn post hoc tests, respectively. Prior to analysis, fc data were log-transformed. Linear regression was used to determine whether stable isotope ratios changed with distance upstream in the Fowl River, using latitude as the measure of distance. Kendall correlation tests were used to test relationships among indicators (fc, $\mathrm{MSC}, \mathrm{NH}_{4}{ }^{+}, \mathrm{ACE}$, SUC) and indicator relationships to environmental variables (temperature, salinity, DO). Indicator concentrations were also compared to particulate carbon concentrations (obtained during elemental analysis), and $\mathrm{pH}$ because previous studies suggest they may cause matrix effects or influence recovery in artificial sweetener analyses (Loos et al. 2009; Mead et al. 2009; Scheurer et al. 2009). 
Table 1 Sampling period classification, corresponding month(s), and environmental data, including water temperature, salinity, and dissolved oxygen (DO) on the day of sampling for this study (20172018) and historical data (2000-2018). River conditions for this study were calculated as the discharge in $\mathrm{m}^{3} \mathrm{~s}^{-1}$ measured at Fowl River averaged over the 2 weeks prior to sampling, while river conditions for the historical data were calculated as the mean Mobile River stage in feet ( $\mathrm{ft}$ ) to be comparable to the historical fc dataset. For this study, sum of precipitation for 3 days prior to sampling and mean wind speed (scalar average) and direction (unit-vector average) for the day of sampling are also shown. Error is reported as standard error. indicates data not available

\begin{tabular}{|c|c|c|c|c|c|c|c|c|}
\hline Classification & Sampling month(s) & Temperature $\left({ }^{\circ} \mathbf{C}\right)$ & Salinity & DO $\left(\mathrm{mg} \mathrm{L}^{-1}\right)$ & $\begin{array}{l}\text { River discharge } \\
\left(\mathrm{m}^{3} \mathrm{~s}^{-1}\right) \text { or stage } \\
(\mathrm{ft})\end{array}$ & $\begin{array}{l}\text { Total } \\
\text { rainfall } \\
(\mathrm{cm})\end{array}$ & $\begin{array}{l}\text { Wind speed } \\
\text { (knots) }\end{array}$ & $\begin{array}{l}\text { Wind } \\
\text { direction }\end{array}$ \\
\hline \multicolumn{9}{|l|}{ This study } \\
\hline Warm, dry & Jul, Aug & $31.3 \pm 0.2$ & $6.3 \pm 1.2$ & $5.06 \pm 1.22$ & $1.6 \pm 0.0$ & 0.03 & $8.3 \pm 1.5$ & SE \\
\hline Warm, wet & Nov & $23.4 \pm 0.2$ & $10.5 \pm 1.1$ & $5.39 \pm 0.28$ & $2.3 \pm 0$ & 0.00 & $5.3 \pm 0.06$ & SW \\
\hline Cold, dry & Jan & $9.4 \pm 0.1$ & $14.6 \pm 2.5$ & $10.14 \pm 0.10$ & $1.2 \pm 0.0$ & 0.00 & $11.1 \pm 0.1$ & $\mathrm{NE}$ \\
\hline Cold, wet & $\mathrm{Feb}$ & $16.6 \pm 0.1$ & $2.5 \pm 1.1$ & $6.99 \pm 0.17$ & $2.0 \pm 0.1$ & 17.25 & $12.3 \pm 0.1$ & $\mathrm{NE}$ \\
\hline \multicolumn{9}{|l|}{ Historical data } \\
\hline Warm, dry & Apr-Nov & $28.2 \pm 0.4$ & $20.6 \pm 0.7$ & - & $2.9 \pm 0.1$ & - & - & - \\
\hline Warm, wet & Mar-Nov & $24.5 \pm 0.5$ & $11.3 \pm 1.1$ & - & $6.2 \pm 0.2$ & - & - & - \\
\hline Cold, dry & Oct-Apr & $15.4 \pm 0.7$ & $25.1 \pm 0.8$ & - & $3.0 \pm 0.1$ & - & - & - \\
\hline Cold, wet & Oct-Apr & $15.2 \pm 1.2$ & $13.6 \pm 1.1$ & - & $6.7 \pm 0.2$ & - & - & - \\
\hline
\end{tabular}

To aid application of our data for management purposes at the shellfish farms, we categorized and spatially depicted the relative seasonal influence of key wastewater indicators (fc, artificial sweeteners) at major sites identified in this study and at the nearby shellfish farms. To do this, data for adjacent sites were combined when land use and estimated sources were similar. As a result, indicator concentrations from these sources were compared to sources including the wastewater treatment outflow (WTPO), industrial site (CB), agricultural sites (R6A, R6B), southern residential sites (R2A, R2B, R2C), and northern residential sites (R7A, R7B), as well as at the shellfish farms (FRB1, FRB2) (Fig. 1). Indicator concentrations at each site or combination of sites were averaged for the site groups and compared between the cold, wet period alone, and the remaining sampling periods combined. Data were then assigned a low, medium, elevated, or high level and an associated stoplightstyle color code. For fc, the color code was developed based on two independent approaches. First, data were separated based on quartiles within the dataset with low $($ green $)=1$ st quartile minimum concentrations; medium $($ yellow $)=1 \mathrm{st}$ quartile median; elevated (orange) $=3$ rd quartile median; high $(\mathrm{red})=3$ rd quartile maximum. Second, ADPH limits for shellfish harvesting (low $<14 \mathrm{cfu} 100 \mathrm{~mL}^{-1}(1.1 \log \mathrm{cfu}$ $100 \mathrm{~mL}^{-1}$ )), recreation (medium $<200 \mathrm{cfu} 100 \mathrm{~mL}^{-1}(2.3$ $\log$ cfu $100 \mathrm{~mL}^{-1}$ )), and fishing/boating (elevated $<$ and high > $1000 \mathrm{cfu} 100 \mathrm{~mL}^{-1}$ (3.0 log cfu $100 \mathrm{~mL}^{-1}$ ); USEPA 2003) were assigned to the same data set. Both approaches resulted in the same assignment levels. ACE and SUC were similarly classified relative to tap water concentrations, with low $($ green $)=\mathrm{ACE}$ and SUC concentrations within 1 average standard deviation of tap water; medium (yellow) $\geq 1$ to
5 standard deviations (averaged over all zones) above the average tap water reading; elevated (orange) $\geq 5$ to 10 standard deviations above tap water; and high (red) $\geq 10$ standard deviations above tap water. To be conservative, for this analysis, the average standard deviation was calculated across all sites; a value considerably higher than the standard deviation associated with replicate measurements of tap water alone.

\section{Historical Data Comparison}

To compare the results from this study to historical data from the area, routine water quality monitoring data from 2000 to 2018 for a site near the mouth of West Fowl River (Station 139A, represented as a Star on Fig. 1) were obtained from the ADPH (B. Webb, personal communication). Data included date of sample collection, water temperature, salinity, Mobile River stage (height of the water surface above the streambed), fc (MPN $100 \mathrm{~mL}^{-1}$ ), and open or closed status of the area to commercial and recreational shellfish harvesting. To be comparable with the newly collected data from this study, the historical dataset was categorized into warm/cold and wet/dry sampling periods based on the ADPH-reported environmental data at the time of sampling ("warm" and "cold" periods differed, $t$-test: $F_{1,160}=391.5$, $p<0.001$; Table 1). Differences among these periods were determined as described above for newly collected data. West Fowl River discharge data were not available for the period of the historical dataset. Hence, data were categorized into dry or wet periods based on the Mobile River stage (measured at the Barry Steam Plant in Bucks, Alabama), which was recorded in the historical data set. The median river stage of 4.0 feet $(1.2 \mathrm{~m})$ during the 18-year data set was 
used as the distinction between periods ("wet" and "dry" periods differed, $t$-test: $F_{1,159}=518.5, p<0.001$; Table 1). To determine if historical time periods of high $\mathrm{fc}$ loads were related to river stage or known shoreline activities that could distinguish sources of wastewater to the system (e.g., Chigbu et al. 2005), fc values were plotted through time and against river stage. Linear regression was used to relate fc concentrations to river stage for all time points in the historical data set (2000-2018) and during recent years when shellfish farms were in operation (2010-2018). Outliers were identified as points with standardized residuals $>2$. In the absence of predictive relationships through time, a $t$-test was additionally used to compare mean fc values for 2000-2009 to those for 2010-2018.

\section{Results}

\section{Environmental Conditions}

Salinity was lower in the cold, wet period than in the warm, wet and cold, dry periods (Table 1; Kruskal-Wallis, $X^{2}=26.45, d f=3, p<0.001$; Dunn's $p<0.01$ for all significant pairwise comparisons). Salinity was similar during the cold, wet and warm, dry periods when local rainfall was documented (Table 1). Salinity also decreased with latitude upstream in WFR (salinity $=6716-221$ latitude, $R^{2}=0.18$, $F_{\text {reg1,60 }}=13.6, p<0.001$ ). Dissolved oxygen (DO) was highest in the cold, dry period, followed by the cold, wet period, and then both warm periods, which did not differ (Table 1; ANOVA, $F_{3,58}=119.7, p<0.001$; Tukey's $p<0.001$ for all significant pairwise comparisons). Wind speeds were higher and from the north during cold periods and showed no differences between wet and dry periods within seasons (Table 1).

\section{Microbial Indicators}

Fecal coliforms (fc) showed patterns with site and sampling period. Fc ranged from $<5$ to $5250 \mathrm{CFU} 100 \mathrm{~mL}^{-1}$ across all sampling sites and time periods (Fig. 2a, b). Mean concentrations were higher in the cold wet period (ANOVA: $F_{3,58}=36.60, p<0.001$; Tukey's $p<0.001$ ) and year-round at sites adjacent to residential (R2, R7) and agricultural (R6) areas (Figs. 1 and 2a, b). Male-specific coliphage (MSC) concentrations were overall low (57\% of samples were below detection), ranging from below detection $(<10 \mathrm{PFU}$ $100 \mathrm{~mL}^{-1}$ ) to $60 \mathrm{PFU} 100 \mathrm{~mL}^{-1}$ across all sampling sites and periods (Figure $\mathrm{S} 1$ ). MSC concentrations were mostly above the lower detection limit in warm periods, and this limited number of samples showed no discernable pattern among sites (Kruskal-Wallis, $X^{2}=16.97, d f=15, p=0.32$ ). Hence, MSC results were excluded from further analysis.

\section{Nutrient Indicators}

Of the nutrients measured (total dissolved nitrogen (TDN), dissolved organic nitrogen (DON), dissolved inorganic nitrogen (DIN), $\mathrm{NO}_{2}^{-}, \mathrm{NO}_{3}^{-}, \mathrm{NH}_{4}{ }^{+} ; c f$ Figure S2), only $\mathrm{NH}_{4}{ }^{+}$ and DIN showed patterns with site or sampling period; $\mathrm{NH}_{4}{ }^{+}$ also comprised the majority of DIN in all samples. $\mathrm{NH}_{4}{ }^{+}$ concentrations ranged from below detection to $9.58 \mu \mathrm{M}$ and were highest during the cold, wet period (ANOVA, $F_{3,58}=30.18, p<0.001$, Tukey's $p<0.001$; Fig. $2 \mathrm{a}$, c). $\mathrm{NH}_{4}{ }^{+}$ concentrations peaked at the residential areas and mid-river during all sampling periods (Fig. 2a, c).

\section{Stable Isotope Indicators}

Carbon and nitrogen stable isotope ratios showed patterns with site and sampling date. $\delta^{13} \mathrm{C}$ ratios ranged from -34.80 to $-23.32 \%$ and were lower in warm periods than in cold periods (Kruskal-Wallis: $X^{2}=31.60, d f=3$, $p<0.001$; Dunn's: $p<0.01$; Fig. 3a). In both the warm and cold periods, carbon stable isotope ratios decreased moving upstream (warm: $y=1928.21-64.49 x, R^{2}=0.24$, $F_{\text {reg1,22 }}=8.09, p<0.01$; cold: $y=1230.74-41.39 x$, $R^{2}=0.42, F_{\text {reg } 1,18}=14.81, p<0.01 ;$ Fig. $\left.3 a\right) . \delta^{15} \mathrm{~N}$ ratios ranged from 1.4 to $7.8 \%$ and were lower in the cold wet period (ANOVA: $F_{3,58}=35.42, p<0.001$; Tukey's: $p<0.001$; Fig. 3b). Within each sampling period, $\delta^{15} \mathrm{~N}$ values were lowest at sites in R2, R6, and R7 (residential and agriculture sites). $\delta^{15} \mathrm{~N}$ ratios decreased upstream in the cold wet period $\left(y=1204.91-39.57 x, R^{2}=0.31, F_{\text {reg1 } 110}=5.99\right.$, $p=0.03$ ). As a result, $\delta^{13} \mathrm{C}$ and $\delta^{15} \mathrm{~N}$ values were positively correlated in the cold wet period, and $\delta^{13} \mathrm{C}$ increased more gradually (at a slower rate) with increasing $\delta^{15} \mathrm{~N}$ than in other seasons (Fig. 3b).

\section{Artificial Sweeteners}

Acesulfame (ACE) concentrations ranged from 0.004 to $0.05 \mu \mathrm{g} \mathrm{L}^{-1}$ (Fig. 4a, b), and sucralose (SUC) concentrations ranged from below quantification to $>0.8 \mu \mathrm{g} \mathrm{L}^{-1}$ (Fig. 4a, b). In the cold wet period, ACE and SUC were both the highest at the WTPO, with the highest SUC measurement $\left(>0.8 \mu \mathrm{g} \mathrm{L}^{-1}\right)$ significantly exceeding the highest concentration in the calibration curve; diluting the sample for reanalysis to define an exact concentration was deemed not necessary for the purpose of this study because the results sufficiently demonstrate exceptionally high concentrations in the WTPO outflow. ACE and SUC remained detectable near the shellfish farm and in the southern residential area during the cold wet season, and both ACE and SUC concentrations appeared to decrease upstream in WFR, with SUC becoming undetectable in the agricultural and northern residential areas (Fig. 4a). During other 


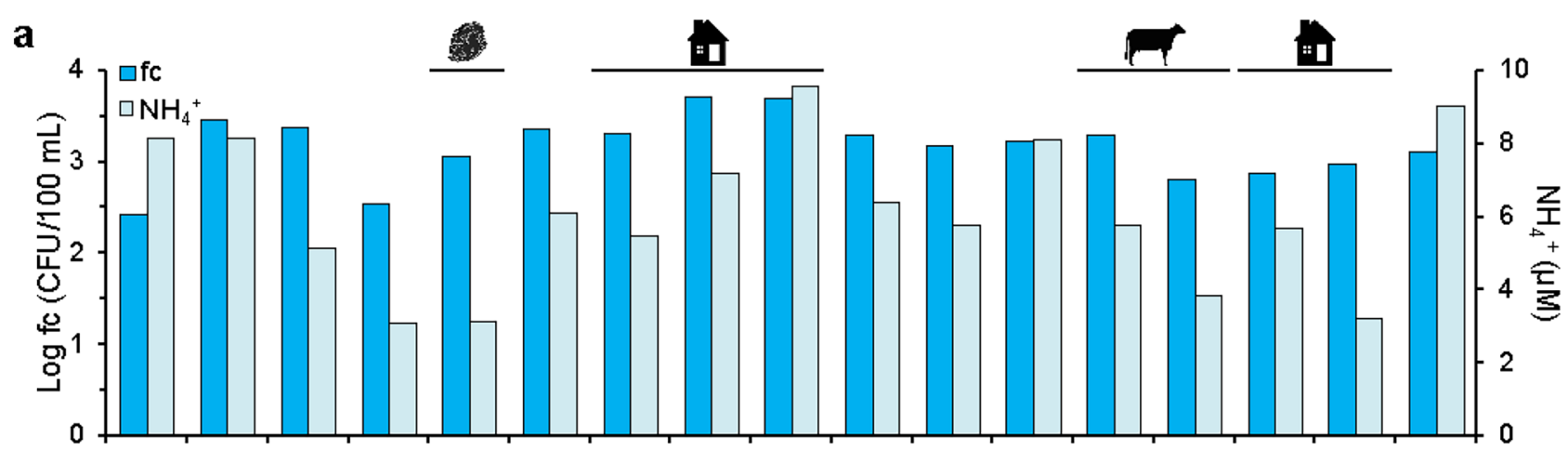

b
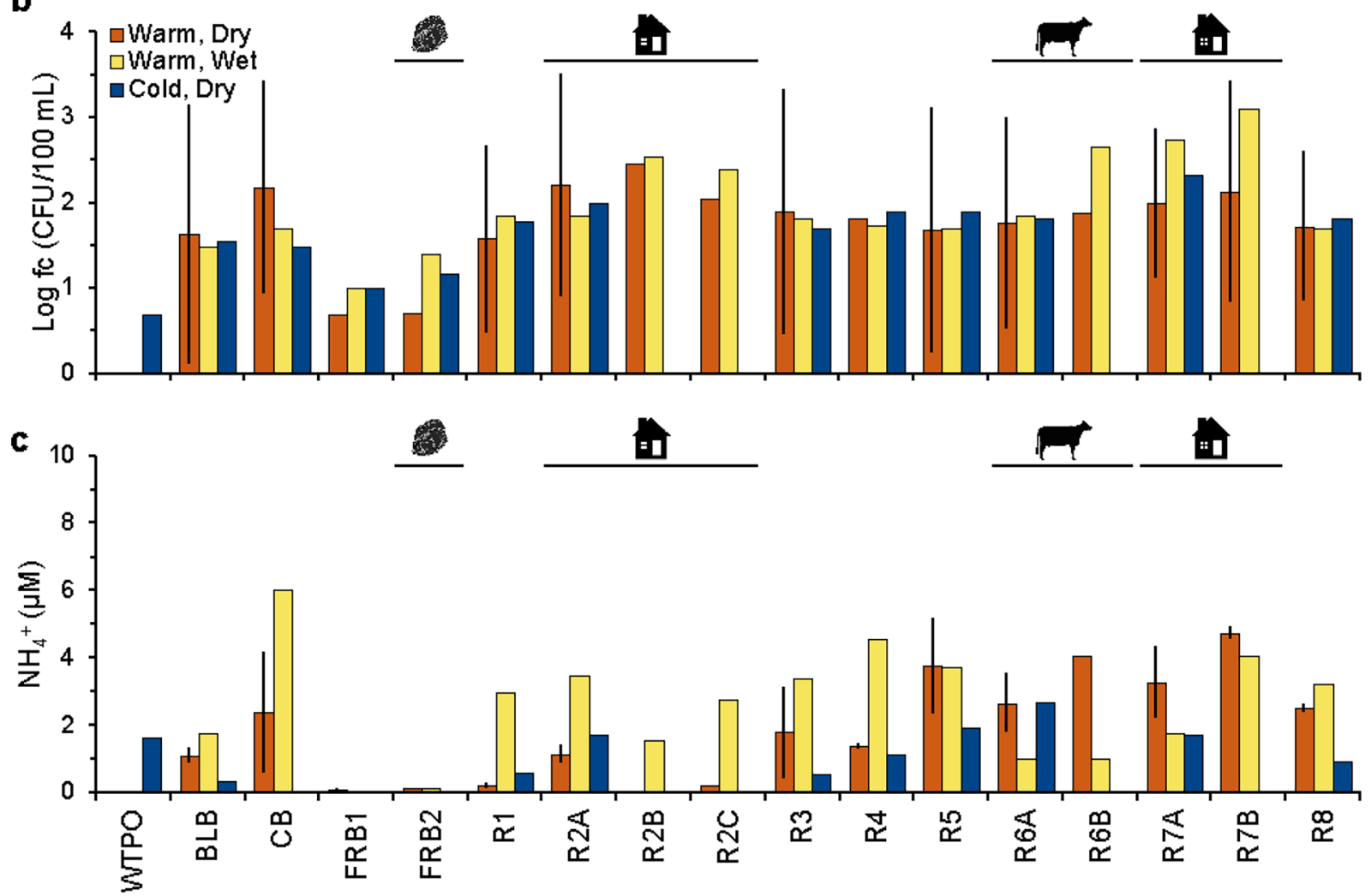

Fig. 2 Log-transformed fecal coliform (fc) and ammonium $\left(\mathrm{NH}_{4}{ }^{+}\right)$ concentrations at each site during the cold, wet (a), and other sampling periods $(\mathbf{b}, \mathbf{c})$. Error bars are the standard error on the average of two independent "warm, dry" sampling dates at repeated sites. Icons indicate sampling sites at the shellfish farm (oyster), residential sites (house), and agricultural sites (cattle) seasons, the concentrations of ACE and SUC were higher than during the cold wet season, with ACE values highest upstream in the river, but no clear spatial pattern relative to the shellfish farms (Fig. 4b).

\section{Correlations Among Indicators}

When data were combined for all sites to test correlations between indicators (fc, $\mathrm{MSC}, \mathrm{NH}_{4}{ }^{+}, \mathrm{ACE}, \mathrm{SUC}$ ) and temperature, salinity, dissolved oxygen (DO), $\mathrm{pH}$, and particulate carbon (Table 2), we found fc and particulate carbon were positively correlated, and ACE and SUC were each positively correlated with $\mathrm{pH}$, salinity, and with each other during the cold wet period. When data were combined for all other sampling periods (excluding cold wet), fc was negatively correlated with salinity and $\mathrm{pH}$, and $\mathrm{NH}_{4}{ }^{+}$was negatively correlated with salinity. No other correlations were detected among the tested indicators. 

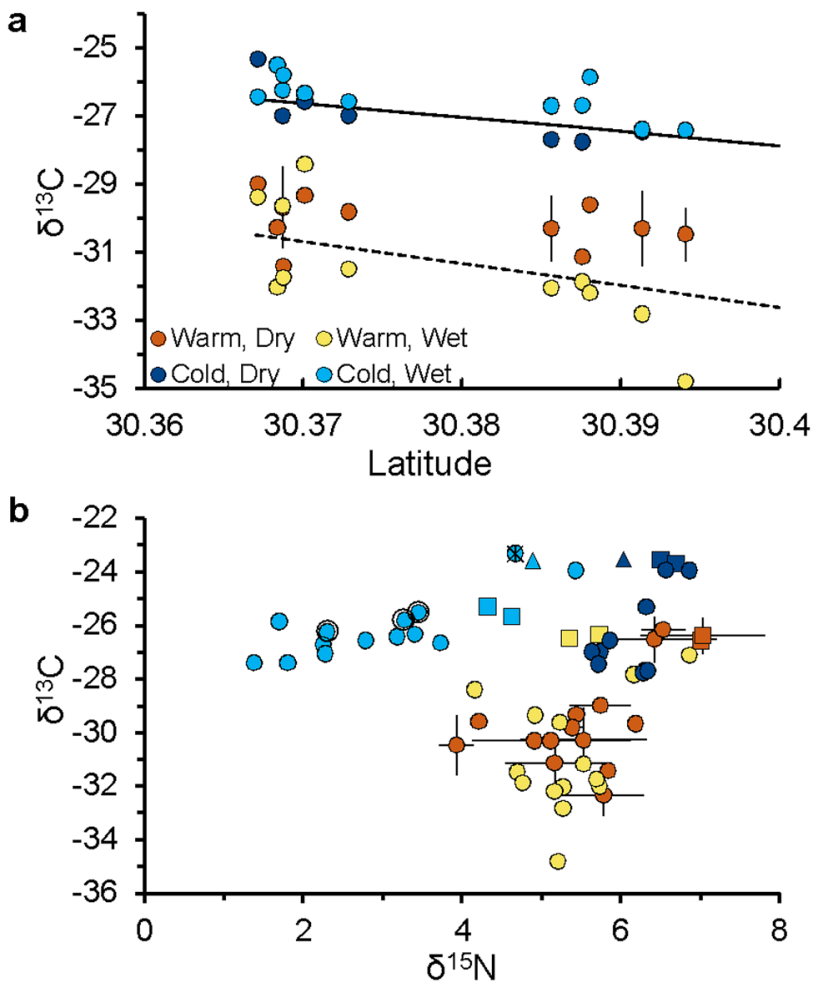

Fig. 3 Carbon stable isotope values in water at river sites compared to latitude (a) and carbon and nitrogen stable isotope values in water during each sampling period at each site (b). Error bars are the standard error on the average of two independent "warm, dry" sampling dates at repeated sites. In panel $\mathbf{b}$, samples are separated by location, including WTP outfall (triangles), nearby shoreline sites (BLB, CB; squares), and Fowl River Bay or West Fowl River (circles). Values at the southern residential site (R2) during the cold, wet period are double-circled, and the value at the shellfish farm (FRB2) during this period is marked with an $\mathrm{X}$

\section{Comparing Potential Sources for Management}

Based on the seasonal differences we found in wastewater indicator values among sites, we opted to combine and compare data at potential source areas to data at the shellfish farms for the cold wet period separately from other sampling periods (Fig. 5). We found fc concentrations were elevated (WTPO, northern residential sites) or high (industrial, southern residential, agricultural sites) at all major sources and elevated at the shellfish farms in the cold wet period (Fig. 5a). ACE and SUC were low (industrial, northern residential, agricultural sites), medium (ACE, southern residential sites), or elevated/high (WTPO) at the source sites and medium/elevated at the shellfish farms (Fig. 5a). In all other periods combined, fc ranged from low (WTPO) to elevated (northern residential sites) at sources and was classified as medium at the shellfish farms. ACE and SUC ranged from low (agricultural sites) to elevated (ACE, northern residential sites) and were classified as medium at the shellfish farms (Fig. 5b).

\section{Comparison to Historical Datasets}

Fc concentrations in the historical dataset from Fowl River Bay, sampled near the shellfish farm (Fig. 1), ranged from 1.8 to $540.0 \mathrm{MPN} 100 \mathrm{~mL}^{-1}$ (Fig. 6a). As found in this study, historical fc concentrations were the highest during cold wet periods, but the cold wet did not differ from the cold dry period, and both cold periods were higher than the warm dry period (ANOVA: $F_{3,156}=6.7$, $p<0.001$, Tukey's $p<0.05$ for all significant comparisons). Although mean fc concentrations during the previous decade (2000-2009, mean: 19.8 $\pm 9.0 \mathrm{MPN} 100 \mathrm{~mL}^{-1}$, median: 1.8 MPN $100 \mathrm{~mL}^{-1}$ ) were slightly higher than in recent years when shellfish farms were in operation (Fig. 6b; 2010-2018, mean: $12.4 \pm 2.9$ MPN $100 \mathrm{~mL}^{-1}$, median: $2.0 \mathrm{MPN} 100 \mathrm{~mL}^{-1}$; $t$-test: $F_{1,158}=5.1, p=0.03$ ), higher than typical (outlier) fc values were documented in 2016 (Fig. 6b). These outliers were coincidental with shoreline construction to upgrade septic systems and create new sewer connections at the southern residential sites in West Fowl River (R2, R2A, R2B; T. Micher, Mobile County Health Department, personal communication).

River stage was not predictive of fc concentrations for all years combined (2000-2018) or during recent years (2010-2018) (Fig. 6a, b). There were six periods of documented shellfish harvest closure during 2010-2018 (Fig. 6c, gray bars), indicating river stage was likely higher than $8.0 \mathrm{ft}(2.4 \mathrm{~m})$ and triggered the closures. The recorded river stage at the time of $\mathrm{fc}$ sampling was never above 8.0 $\mathrm{ft}$, however, likely due to sampling restrictions: ADPH does not collect water quality samples until river stage has fallen and the area could be reopened. Despite this sampling lag, closure periods typically corresponded to elevated fc values, except during construction in 2016 (Fig. 6c, red box), when fc values were very high, but there was no closure (river stage was 3.0-4.5 ft; Fig. 6b, white triangles).

\section{Discussion}

Our results suggest wastewater from a combination of residential, agricultural, industrial, and wastewater treatment plant (WTP) outfall sources may reach shellfish farms, particularly during cold wet periods in the northern Mississippi Sound. Residential and agricultural areas and WTPs have been confirmed or suspected fecal coliform (fc) sources in this and other systems in the past but rarely quantified in tandem (Determan et al. 1985; Gregory and Fricke 2001; Jamieson et al. 2003; Daskin et al. 2008; 
Fig. 4 Artificial sweetener (ACE, SUC) concentrations at sites during the cold, wet (a), and during other sampling periods averaged (b). Concentrations in tap water are suggestive of background values but do not have seasonal information. $\mathrm{ND}=$ values below detection, and empty bins indicate insufficient sample for analyses at that location during the sampling period. Error bars are standard error a

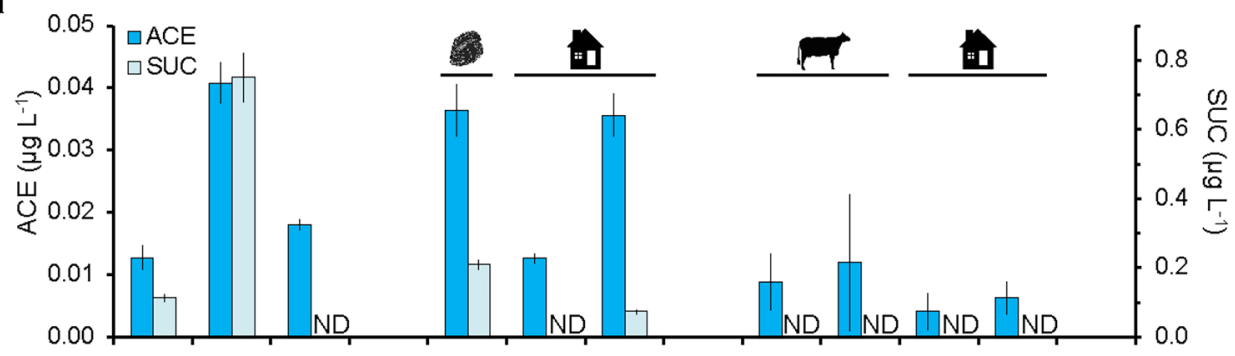

b

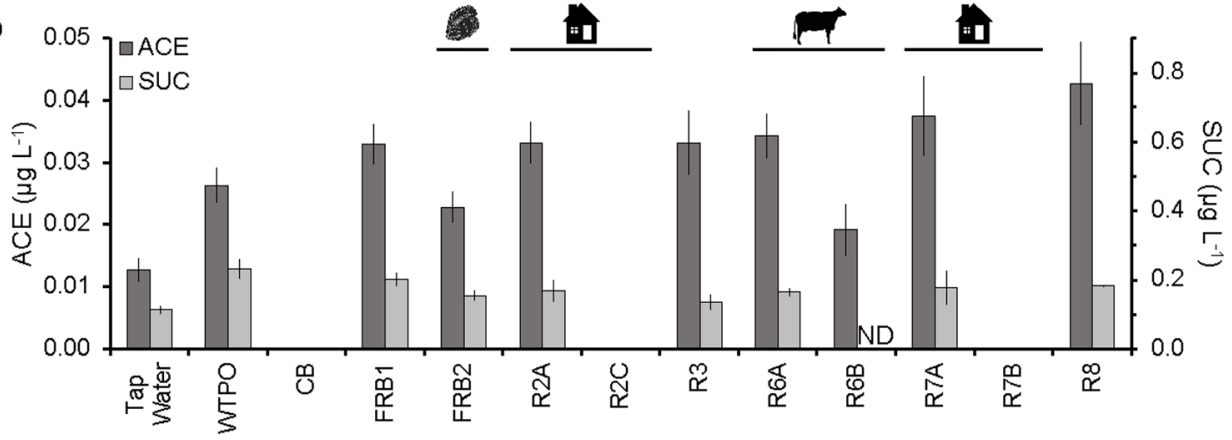

Biancani et al. 2012). Higher concentrations of some wastewater indicators during the cold wet period are likely due to higher runoff from a combination of increased precipitation and river discharge (Lewis et al. 2005; Raña and Domingo 2017; Padovan et al. 2020). The particularly high fc concentrations at agricultural and industrial sites during this period support this idea, with livestock runoff representing a potentially major source of fc to coastal waters globally (Lewis et al. 2005; Blanch et al. 2006; Pandey et al. 2014). Cold periods are characterized by dieback or reduced growth of vegetation on the shoreline, which can increase surface flow and delivery of nutrients from runoff (e.g.,

Table 2 Kendall's tau and $p$-value of significant indicator (fecal coliform (fc), $\mathrm{NH}_{4}{ }^{+}$, acesulfame (ACE), sucralose (SUC)) correlations in the cold, wet period, and in all other sampling periods combined. Temperature, salinity, dissolved oxygen (DO), $\mathrm{pH}$, and particulate carbon were included in analysis. Correlations were only run for samples that had data for all indicators

\begin{tabular}{lllc}
\hline Variable 1 & Variable 2 & tau & $\boldsymbol{p}$ \\
\hline Cold, wet $(\boldsymbol{n = 9 )})$ & & & \\
fc & Carbon & 0.87 & $<0.01$ \\
ACE & Salinity & 0.88 & $<0.01$ \\
ACE & pH & 0.83 & $<0.001$ \\
SUC & Salinity & 0.81 & 0.01 \\
SUC & pH & 0.69 & 0.02 \\
ACE & SUC & 0.76 & 0.01 \\
All other periods $(\boldsymbol{n}=\mathbf{1 1})$ & & \\
fc & Salinity & -0.67 & $<0.01$ \\
$\mathrm{fc}^{+}$ & pH & -0.87 & 0.02 \\
$\mathrm{NH}_{4}{ }^{+}$ & Salinity & -0.51 & 0.04 \\
\hline
\end{tabular}

Ghosh et al. 2016), allowing more direct sheeting as well as delivery and growth of indicator microbes from sources on land to waterways despite colder temperatures that may otherwise limit bacterial abundance (e.g. Mallin et al. 2001). Of note, during this study, despite higher discharge in the warm wet period, salinity was higher than in the warm dry period, suggesting other environmental factors such as lower local rainfall and southerly wind direction may have mediated the effects of discharge in the warm, wet season. Consistent with these results, previous studies in our region and elsewhere have found rainfall, which affects discharge, to be more important than temperature to delivery of fc from land to water, depending on watershed characteristics such as land cover and interannual variation in weather (Chigbu et al. 2004; Jeon et al. 2019; Wang and Deng 2019). These findings suggest that wastewater indicator concentrations at sources and, in turn, at shellfish farms may be predictable based on seasonal discharge, weather, and runoff patterns.

The combination of higher $\mathrm{fc}, \mathrm{NH}_{4}{ }^{+}$, and artificial sweeteners during the cold wet period in this study suggests wastewater entering the system was derived, at least in part, from less processed and human-specific sources during the cold wet period. While high fc concentrations may be related to waste from any warm-blooded animal, elevated ammonium is consistent with nitrogen loading from fertilizer or directly discharged human waste (Costa et al. 1992; Valiela et al. 1992, 1997). The concomitantly higher concentrations of acesulfame (ACE) and sucralose (SUC) at the WTP and some residential areas corroborate human sewage inputs at these sources. The relatively high fc and $\mathrm{NH}_{4}^{+}$values year-round at the southern residential 
Fig. 5 Relative concentrations of fecal coliforms (fc), acesulfame (A), and sucralose (S) among sampling zones during the cold, wet (a), and all other (b) periods. Zones were defined as treated sewage (WTPO; outfall pipe), industrial (CB; city skyline), shellfish farms (FRB1, FRB2; oyster), southern residential (R2, R2A, R2B; house), agricultural (R6A, R6B; cattle), and northern residential (R7A, R7B; house). Colors indicate low (green), medium (yellow), elevated (orange), and high (red) concentrations. Fc data were categorized based on quantiles (low (green) $\leq 13.75$; medium $($ yellow $)=13.76-$ 87.5 ; elevated (orange) $=87.6-$ 1000; high (red) $\geq 5250 \mathrm{cfu}$ $\left.100 \mathrm{~mL}^{-1}\right)$. ACE and SUC were categorized relative to tap water concentrations (low $($ green $)=$ within 1 average standard deviation; medium (yellow) $\geq 1$ to 5 standard deviations; elevated (orange) $\geq 5$ to 10 standard deviations; high (red) $\geq 10$ standard deviations)
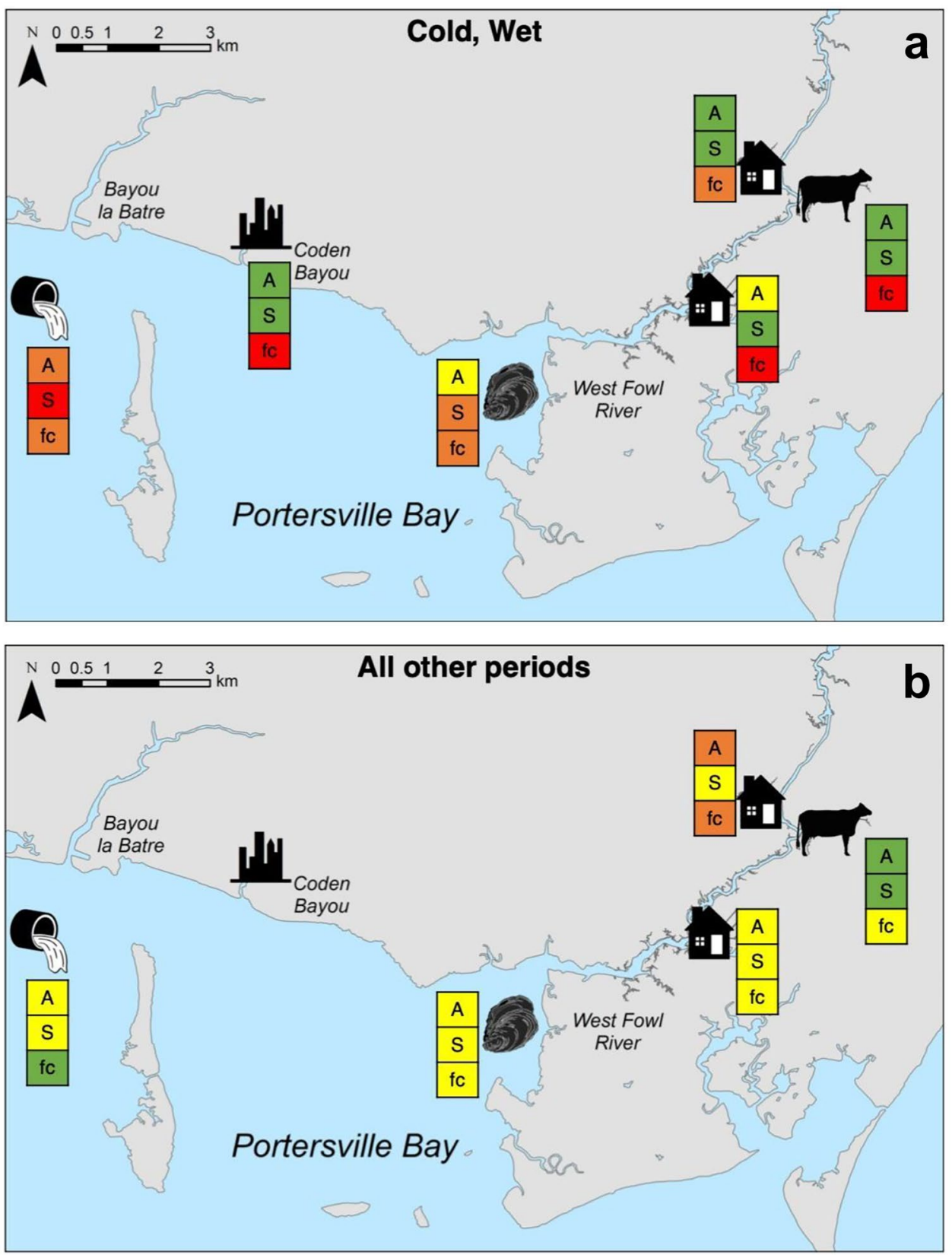

site (R2) combined with low $\delta^{15} \mathrm{~N}$ at this site during the cold wet period further suggest a source of unprocessed wastewater at this particular location. $\delta^{15} \mathrm{~N}$ is typically lighter in suspended particulate matter (SPM) from raw or unprocessed wastewater than SPM from enhanced nutrient removal WTPs or septic seepage through groundwater (e.g., McClelland and Valiela 1998; Tucker et al. 1999; Carmichael et al. 2004; Savage 2005; Biancani et al. 2012), suggesting an improperly functioning septic system or other direct discharge at the southern residential site. Dye study results indicate discharge from the Bayou la Batre WTP may reach shallow sites in the West Fowl River during south to southwest winds (FDA 2014). During the cold wet sampling period, the predominant wind was from the northeast (Table 1), but southerly winds on preceding days could have altered the circulation so that the water carried WTP-associated indicators to the shellfish farms (ARCOS 2020). The similar concentrations of ACE and SUC at shellfish farms among sampling periods suggesting that human sewage influence on the area may be consistent year-round and independent of surface runoff, compared to the sources that convey fc. Lack of regularly detectable male-specific coliphage (MSC) is also consistent with relatively low human municipal wastewater influence. Hence, although human-derived wastewater indicators were detected year-round at shellfish farms and nearby sources, 
Fig. 6 Historical fecal coliform (fc) data (2000-2018) collected by Alabama Department of Public Health (ADPH) at their monitoring site in Fowl River Bay compared to river stage of the Mobile River (a), data for the most recent years alone (2010-2018) (b), and values through time (c). Gray horizontal bars indicate periods of ADPH shellfish area closure in Portersville Bay, where shellfish farms are located. The red box marks Autumn 2016, a period of active construction associated with removal or upgrades of septic systems near a residential site (R2) in West Fowl River. ADPH fc samples taken during Autumn 2016 are indicated by white triangles

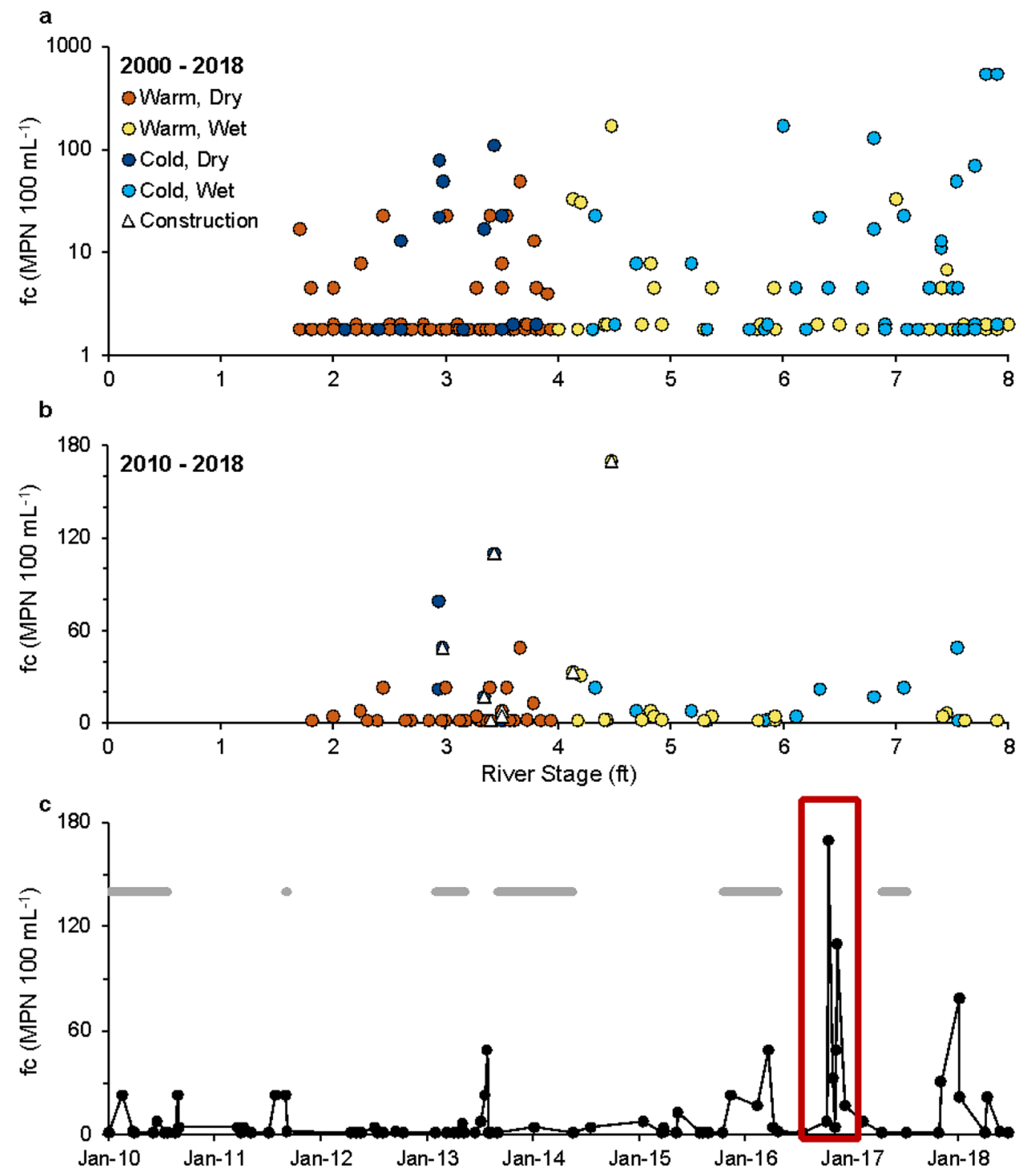

seasonal runoff events may have had a greater influence on fc concentrations that prompt shellfish area closures at these sites than variation in human sewage alone.

Our findings support the use of multiple indicators to detect and distinguish wastewater sources. It is not surprising that fc concentrations were a good wastewater indicator across sampling periods for residential sites but not the WTP because treatment is expected to effectively reduce or remove microbial indicators (FDA 2014). ACE and SUC better detected WTP influence than fc because they are only removed with advanced treatment such as ozone or reverse osmosis (Oppenheimer et al. 2011; James et al. 2016). In this system, ACE was found at higher concentrations across more sites than SUC, suggesting that ACE was delivered at higher concentrations than SUC throughout the study area. SUC degrades very slowly and only at low $\mathrm{pH}(\mathrm{pH} 3$; Mead et al. 2009), enabling subsequent wastewater detection and greater potential as a more specific indicator of human wastewater sources (e.g., WTP, residential areas) than ACE in this system. Previous studies in the US have identified SUC as an effective wastewater indicator (Mawhinney et al. 2011; Oppenheimer et al. 2011; James et al. 2016), while European and Asian studies found ACE to be more effective (Tran et al. 2014; Mijangos et al. 2018), potentially due to regional differences in consumption. $\delta^{15} \mathrm{~N}$ was useful to help detect an area of potential raw sewage source for remediation, while $\delta^{13} \mathrm{C}$ demonstrated increasing freshwater influences upstream. $\delta^{13} \mathrm{C}$ was less useful to relate wastewater to land-derived sources in this system because values at all sites indicated freshwater contributions $\left(\delta^{13} \mathrm{C}\right.$ values $<-25 \%$ ). Stable isotope values, however, reflected a decoupling of the $\delta^{13} \mathrm{C}$ and $\delta^{15} \mathrm{~N}$ values during the cold wet period, a pattern that cannot be fully explained given that $\delta^{13} \mathrm{C}$ values were expected to be lower rather than higher during periods of high discharge and runoff. Unlike all other indicators, river stage did not appear to be an effective 
predictor of wastewater influence in any season. Analysis of the long-term monitoring dataset revealed that, historically, the Mobile River stage appeared to be a poor indicator of fc concentrations in Fowl River Bay, although this is likely due in part to the state's sampling restrictions during river stage-triggered harvest closures. Future studies may benefit from higher temporal resolution sampling to better assess the effects of environmental factors on wastewater indicators and quantify sample-to-sample variation. While the idea to use multiple indicators to detect wastewater influence is not new (e.g., Griffin et al. 2001; National Research Council 2004; Biancani et al. 2012), in this study, we were able to show that combinations of traditional and novel indicators were useful to detect wastewater influence and help define sources under different environmental conditions.

Finally, this study suggests that indicators can be added to a system as an unintended consequence of construction, including work intended to proactively improve water quality. The spike in fc in this system during the Autumn 2016 construction may be attributed to the active disruption of sanitary sewer and septic systems and mobilization of previously buried sewage and associated indicators from soils and sediments and re-entry to the water column (Grimes 1975; Struck 1988; Jamieson et al. 2003). By introducing and resuspending fc bacteria in the water column, this indicator mobilization may have caused the area to be more susceptible to future rain-driven sediment disturbances, with potential to contribute to downstream shellfish area closures in the subsequent years. To safeguard human health and protect the livelihood of shellfish growers, it will be necessary to consider the combination of sources along with local weather patterns and the location and timing of coastal construction projects that may affect wastewater indicator concentrations.

Overall, our analyses revealed that both the WTP and residential areas in West Fowl River were potential sources of human-specific wastewater to shellfish farms year-round, with these sources in combination with agricultural and industrial sites likely contributing additional fc associated with runoff, particularly during cold wet periods. Managers will benefit from using multiple indicators to detect and define these wastewater sources to a system, define targets for monitoring or remediation, and improve metrics for determining shellfish area closures. The potentially complex interaction of multiple indicators, however, can be challenging to summarize and convey to decision-makers. A trafficlight icon display such as the one prepared for this study (Fig. 5) has been successfully used to simplify information from multiple indicators to guide end-users in selection of healthy or safe foods, understanding water quality, and managing fisheries (e.g., Caddy 2004; Koenigstorfer et al. 2014, USEPA 2019). We demonstrate the benefits of this approach to seasonal source tracking for wastewater that may focus and enhance management efforts for shellfish growing areas.
Supplementary Information The online version contains supplementary material available at https://doi.org/10.1007/s12237-021-01033-x.

Acknowledgements We thank E. Hieb, H. Gancel, J. Nash, C. Williams, G. Forster, S. Bulls, P. Stott, D. Hill, and staff at the DISL and USFDA for field and lab assistance.

Funding This study was funded in part by the Dauphin Island Sea Lab/U.S. Food and Drug Administration Joint Graduate Fellowship Program (\#5U19FD005923-04), a Mobile Bay National Estuary Program small grant award to RHC, and a Center for Environmental Resiliency at the University of South Alabama award to AS. This work is financially supported by the NSF CHE 1039944.

Open Access This article is licensed under a Creative Commons Attribution 4.0 International License, which permits use, sharing, adaptation, distribution and reproduction in any medium or format, as long as you give appropriate credit to the original author(s) and the source, provide a link to the Creative Commons licence, and indicate if changes were made. The images or other third party material in this article are included in the article's Creative Commons licence, unless indicated otherwise in a credit line to the material. If material is not included in the article's Creative Commons licence and your intended use is not permitted by statutory regulation or exceeds the permitted use, you will need to obtain permission directly from the copyright holder. To view a copy of this licence, visit http://creativecommons.org/licenses/by/4.0/.

\section{References}

ADEM. 2019. Bayou la Batre WWTF Permit AL0078921.

Ao, Y. 2018. Bayou La Batre WWTP Computer modeling results. U.S. Food and Drug Administration, College Park, MD.

ARCOS. 2020. Alabama's real-time coastal observing system (20102018). Cedar Point Station data. https://arcos.disl.org/stations/ disl_stations?stationnew $=830$.

Armon, R., and Y. Kott. 1996. Bacteriophages as indicators of pollution. Critical Reviews in Environmental Science and Technology 26: 299-335.

Biancani, P.J., R.H. Carmichael, J.H. Daskin, W. Burkhardt, and K.R. Calci. 2012. Seasonal and spatial effects of wastewater effluent on growth, survival, and accumulation of microbial contaminants by oysters in Mobile Bay, Alabama. Estuaries and Coasts 35: 121-131. https://doi.org/10.1007/s12237-011-9421-7.

Blanch, A.R., L. Belanche-Muñoz, X. Bonjoch, J. Ebdon, C. Gantzer, F. Lucena, J. Ottoson, C. Kourtis, A. Iversen, I. Kühn, and I. and L. Mocé. 2006. Integrated analysis of established and novel microbial and chemical methods for microbial source tracking. Applied and Environment Microbiology 72: 5915-5926.

Burkhardt, W.I., and K.R. Calci. 2000. Selective accumulation may account for shellfish-associated viral illness. Applied and Environment Microbiology 66: 1375-1378.

Byrd, L.A., C. Collins, J. McCool, G. Dunn, and B. Webb. 2012. Rules of Alabama State Board of Health, Bureau of Environmental Services, Chapter 420-3-18, For Shellfish Sanitation.

Cabelli, V.J. 1990. Microbial indicator levels in shellfish, water and sediments from the Upper Narragansett Bay conditional shellfish-growing area. 67. Narragansett Bay Project, EPA, EHBM, NBP-90-32.

Caddy, J.F. 2004. Current usage of fisheries indicators and reference points, and their potential application to management of fisheries for marine invertebrates. Canadian Journal of Fisheries and Aquatic Sciences 61: 1307-1324. 
Calci, K.R., W. Burkhardt, W.D. Watkins, and S.R. Rippey. 1998. Occurrence of male-specific bacteriophage in feral and domestic animal wastes, human feces, and human-associated wastewaters. Applied and Environment Microbiology 64: 5027-5029.

Carmichael, R.H., B. Annett, and I. Valiela. 2004. Nitrogen loading to Pleasant Bay, Cape Cod: Application of models and stable isotopes to detect incipient nutrient enrichment of estuaries. Marine Pollution Bulletin 48: 137-143. https://doi.org/10.1016/S0025326X(03)00372-2.

Chigbu, P., S. Gordon, and T. Strange. 2004. Influence of inter-annual variations in climatic factors on fecal coliform levels in Mississippi Sound. Water Research 38: 4341-4352.

Chigbu, P., S. Gordon, and P.B. Tchounwou. 2005. The seasonality of fecal coliform bacteria pollution and its influence on closures of shellfish harvesting areas in Mississippi Sound. International Journal of Environmental Research and Public Health 2: 362373. https://doi.org/10.3390/ijerph2005020023.

Cloern, J.E., P.C. Abreu, J. Carstensen, L. Chauvaud, R. Elmgren, J. Grall, and J. Xu. 2016. Human activities and climate variability drive fast-paced change across the world's estuarine-coastal ecosystems. Global Change Biology 22: 513-529.

Costa, J.E., B.L. Howes, A.E. Giblin, and I. Valiela. 1992. Monitoring Nitrogen and Indicators of Nitrogen Loading to Support Management Action in Buzzards Bay. https://doi.org/10.1007/ 978-1-4615-4659-7.

Darrow, E.S., R.H. Carmichael, K.R. Calci, and W. Burkhardt. 2016. Land-use related changes to sedimentary organic matter in tidal creeks of the northern Gulf of Mexico. Limnology and Oceanography 62: 686-705. https://doi.org/10.1002/lno.10453.

Daskin, J.H., K.R. Calci, W. Burkhardt, and R.H. Carmichael. 2008. Use of $\mathrm{N}$ stable isotope and microbial analyses to define wastewater influence in Mobile Bay, AL. Marine Pollution Bulletin 56: 860-868. https://doi.org/10.1016/j.marpolbul.2008.02.002.

DeBartolomeis, J., and V.J. Cabelli. 1991. Evaluation of an Escherichia coli host strain for enumeration of F male-specific Bacteriophages. Applied and Environment Microbiology 57: 1301-1305.

Determan, T.A., B.M. Carey, W.H. Chamberlain, and D.E. Norton. 1985. Sources affecting the sanitary conditions of water and shellfish in Minter Bay and Burley Lagoon. Olympia, WA. WDOE Report No. 84-10, 186 pp.

Dzwonkowski, B., K. Park, H.K. Ha, W.M. Graham, F.J. Hernandez, and S.P. Powers. 2011. Hydrographic variability on a coastal shelf directly influenced by estuarine outflow. Continental Shelf Research 31: 939-950.

Evans, K.S., K. Athearn, X. Chen, K.P. Bell, and T. Johnson. 2016. Measuring the impact of pollution closures on commercial shellfish harvest: The case of soft-shell clams in Machias Bay, Maine. Ocean \& Coastal Management 130: 196-204. https://doi.org/10. 1016/j.ocecoaman.2016.06.005.

FAO. 2018. The State of World Fisheries and Aquaculture 2018 - Meeting the sustainable development goals. Rome. License: CC BY-NCSA 3.0 IGO. ISBN 978-92-5-130562-1.

FDA. 2014. Evaluating the dilution of wastewater treatment plant effluent, treatment efficiency, and potential microbial impacts on shellfish growing areas in Bayou La Batre, AL: Report of Findings from the March 7-13, 2014 Study Period.

Fry, B. 2006. Stable Isotope Ecology, Springer Science+Business Media, LLC.

Ghosh, S., D.R. Mishra, and A.A. Gitelson. 2016. Long-term monitoring of biophysical characteristics of tidal wetlands in the northern Gulf of Mexico- a methodological approach using MODIS. Remote Sensing of Environment 173: 39-58.

Gregory, M.B., and E.A. Fricke. 2001. Summary of fecal-coliform bacteria concentrations in streams of the Chattahoochee River National Recreation Area, Metropolitan Atlanta, Georgia,
May-October 1994 and 1995. Proceedings of the 2001 Georgia Water Resources Conference. 718-721.

Grice, R., and W.C. Walton. 2020. Alabama Shellfish Aquaculture Situation and Outlook Report 2019. Auburn Univ. Mar. Ext. Res. Cent.https://www.aces.edu/wp-content/uploads/2020/09/ANR2674-Ala-Shellfish-Aquaculture-Report-2019_090120L-G.pdf.

Griffin, D.W., E.K. Lipp, M.R. McLaughlin, and J.B. Rose. 2001. Marine recreation and public health microbiology: Quest for the ideal indicator. BioScience 51: 817-825. https://doi.org/10.1641/ 0006-3568(2001)051[0817:mraphm]2.0.co;2.

Grimes, D.J. 1975. Release of sediment-bound fecal coliforms by dredging. Applied Microbiology 29: 109-111.

Hilton, M.C., and G. Stotzky. 1973. Use of coliphages as indicators of water pollution. Canadian Journal of Microbiology 19: 747-751.

Hof, C. 2000. Use of sweeteners in animal nutrition. Lohmann Information 24: 27-31.

James, C.A., J.P. Miller-Schulze, S. Ultican, A.D. Gipe, and J.E. Baker. 2016. Evaluating contaminants of emerging concern as tracers of wastewater from septic systems. Water Research 101: 241-251. https://doi.org/10.1016/j.watres.2016.05.046.

Jamieson, R.C., R.J. Gordon, S.C. Tattrie, and G.W. Stratton. 2003. Sources and persistence of fecal coliform bacteria in a rural watershed. Water Quality Research Journal Canada 38: 33-47.

Jeon, D.J., M. Ligaray, M. Kim, G. Kim, G. Lee, Y.A. Pachepsky, D.H. Cha, and K.H. Cho. 2019. Evaluating the influence of climate change on the fate and transport of fecal coliform bacteria using the modified SWAT model. Science of the Total Environment 658: 753-762.

Koenigstorfer, J., A. Groeppel-Klein, and F. Kamm. 2014. Healthful food decision making in response to traffic light color-coded nutrition labeling. Journal of Public Policy \& Marketing 33: 65-77.

Lange, F.T., M. Scheurer, and H.J. Brauch. 2012. Artificial sweetenersa recently recognized class of emerging environmental contaminants: A review. Analytical and Bioanalytical Chemistry 403: 2503-2518. https://doi.org/10.1007/s00216-012-5892-z.

Lewis, D.J., E. Atwill, M. Lennox, L. Hou, B. Karle, and K. Tate. 2005. Linking on-farm dairy management practices to storm-flow fecal coliform loading for California coastal watersheds. Environmental Monitoring and Assessment 107: 407-425.

Loos, R., B.M. Gawlik, K. Boettcher, G. Locoro, S. Contini, and G. Bidoglio. 2009. Sucralose screening in European surface waters using a solid-phase extraction-liquid chromatography-triple quadrupole mass spectrometry method. Journal of Chromatography $A$ 1216: 1126-1131.

Mallin, M.A., S.H. Ensign, M.R. McIver, G.C. Shank, and P.K. Fowler. 2001. Demographic, landscape, and meteorological factors controlling the microbial pollution of coastal waters, p. 185-193. In The Ecology and Etiology of Newly Emergy Marine Diseases. Springer.

Mawhinney, D.B., R.B. Young, B.J. Vanderford, T. Borch, and S.A. Snyder. 2011. Artificial sweetener sucralose in U.S. drinking water systems. Environmental Science and Technology 45: 87168722. https://doi.org/10.1021/es202404c.

McCance, W., O.A.H. Jones, M. Edwards, A. Surapaneni, S. Chadalavada, and M. Currell. 2018. Contaminants of emerging concern as novel groundwater tracers for delineating wastewater impacts in urban and peri-urban areas. Water Research 146: 118-133. https:// doi.org/10.1016/j.watres.2018.09.013.

McClelland, J.W., and I. Valiela. 1998. Linking nitrogen in estuarine producers to land-derived sources. Limnology and Oceanography 43: $577-585$.

McClelland, J.W., I. Valiela, and R.H. Michener. 1997. Nitrogen-stable isotope signatures in estuarine food webs: A record of increasing urbanization in coastal watersheds. Limnology and Oceanography 42: 930-937. https://doi.org/10.4319/lo.1997.42.5.0930. 
Mead, R.N., J.B. Morgan, G. Brooks Avery Jr., R.J. Kieber, A.M. Kirk, S.A. Skrabal, and J.D. Willey. 2009. Occurence of the artificial sweetener sucralose in coastal and marine waters of the United States. Marine Chemistry 116: 13-17.

Mijangos, L., H. Ziarrusta, O. Ros, et al. 2018. Occurrence of emerging pollutants in estuaries of the Basque Country: Analysis of sources and distribution, and assessment of the environmental risk. Water Research 147: 152-163. https://doi.org/10.1016/j. watres.2018.09.033.

Mobile Bay National Estuary Program. 2019. West Fowl River Watershed Management Plan.

National Research Council. 2004. Indicators for waterborne pathogens, The National Academies Press.

NSSP. 2019. National Shellfish Sanitation Program Guide for the Control of Molluscan Shellfish. Natl. Shellfish Sanit. Prog. http://www. fda.gov/Food/GuidanceRegulation/FederalStateFoodPrograms/ ucm2006754.htm.

Oppenheimer, J., A. Eaton, M. Badruzzaman, A.W. Haghani, and J.G. Jacangelo. 2011. Occurrence and suitability of sucralose as an indicator compound of wastewater loading to surface waters in urbanized regions. Water Research 45: 4019-4027. https://doi.org/ 10.1016/j.watres.2011.05.014.

Ordóñez, E.Y., J.B. Quintana, R. Rodil, and R. Cela. 2012. Determination of artificial sweeteners in water samples by solid-phase extraction and liquid chromatography-tandem mass spectrometry. Journal of Chromatography A 1256: 197-205.

Padovan, A., K. Kennedy, D. Rose, and K. Gibb. 2020. Microbial quality of wild shellfish in a tropical estuary subject to treated effluent. Environmental Research 181: 108921.

Pandey, P.K., P. Kass, M. Soupir, S. Biswas, and V. Singh. 2014. Contamination of water resources by pathogenic bacteria. $A M B$ Express 4: 51. https://doi.org/10.1186/s13568-014-0051-x.

Popkin, B.M., and C. Hawkes. 2016. Sweetening of the global diet, particularly beverages: Patterns, trends, and policy responses. The Lancet Diabetes and Endocrinology 4: 174-186. https://doi.org/ 10.1016/S2213-8587(15)00419-2.

Raña, J.A., and J.E. Domingo. 2017. Contamination of coliform bacteria in water and fishery resources in manila bay aquaculture farms. The Philippine Journal of Fisheries 24: 98-126.

Rees, G., K. Pond, and D. Kay. 2010. Safe management of shellfish and harvest waters. IWA Publishing, London, UK: World Health Organization (9781843392255).

Rippey, S.R. 1994. Infectious diseases associated with molluscan shellfish consumption. Clinical Microbiology Reviews 7: 419-425.

Rogers, K.M. 1999. Effects of sewage contamination on macro-algae and shellfish at Moa point, New Zealand using stable carbon and nitrogen isotopes. New Zealand Journal of Marine and Freshwater Research 33: 181-188. https://doi.org/10.1080/00288330. 1999.9516868.

Savage, C. 2005. Tracing the influence of sewage nitrogen in a coastal ecosystem using stable nitrogen isotopes. AMBIO: A Journal of the Human Environment 34: 145-150. https://doi.org/10.1639/ 0044-7447.
Scheurer, M., H.J. Brauch, and F.T. Lange. 2009. Analysis and occurrence of seven artificial sweeteners in German waste water and surface water and in soil aquifer treatment (SAT). Analytical and Bioanalytical Chemistry 394: 1585-1594.

Strickland, J.D.H., and T.R. Parsons. 1972. A practical handbook of seawater analysis. A Practical Handbook of Seawater Analysis 167: 185. https://doi.org/10.1002/iroh.19700550118.

Struck, P.H. 1988. The relationship between sediment and fecal coliform levels in a Puget Sound Estuary. Journal of Environmental Health 50: 403-407.

Tran, N.H., J. Hu, J. Li, and S.L. Ong. 2014. Suitability of artificial sweeteners as indicators of raw wastewater contamination in surface water and groundwater. Water Research 48: 443-456. https:// doi.org/10.1016/j.watres.2013.09.053.

Tucker, J., N. Sheats, A.E. Giblin, C.S. Hopkinson, and J.P. Montoya. 1999. Using stable isotopes to trace sewage-derived material through Boston Harbor and Massachusetts Bay. Marine Environment Research 48: 353-375. https://doi.org/10.1016/S01411136(99)00069-0.

USEPA, United States Environmental Protection Agency. 1978. Method 365.3: Phosphorous, All Forms (Colorimetric, Ascorbic Acid, Two Reagent). https://www.epa.gov/sites/production/files/ 2015-08/documents/method_365-3_1978.pdf.

USEPA, United States Environmental Protection Agency. 1993a. Method 351.2, Revision 2.0: Determination of Total Kjeldahl Nitrogen by Semi-Automated Colorimetry.

USEPA, United States Environmental Protection Agency. 1993b. Method 350.1: Determination of ammonium nitrogen by semiautomated colorimetry.

USEPA, United States Environmental Protection Agency. 1993c. Method 353.2, Revision 2.0: Determination of nitrate-nitrite nitrogen by automated colorimetry.

USEPA, United States Environmental Protection Agency. 2003. Bacterial water quality standards for recreational waters (freshwater and marine waters) status report. EPA-823-R-03-008.

USEPA, United States Environmental Protection Agency. 2019. Annual Report Card Shows Good Water Quality in the Main Stem of the Mystic River in 2018. https://www.epa.gov/newsreleases/annualreport-card-shows-good-water-quality-main-stem-mystic-river-2018.

Valiela, I., G. Collins, J. Kremer, K. Lajtha, M. Geist, M. Seely, J. Brawley, and C.H. Sham. 1997. Nitrogen loading from coastal watersheds to receiving estuaries : New method and application. Ecological Applications 7: 358-380.

Valiela, I., K. Foreman, M. LaMontagne, et al. 1992. Couplings of watersheds and coastal waters: Sources and consequences of nutrient enrichment in Waquoit Bay, Massachusetts. Estuaries 15: 443-457.

Valiela, I., G. Tomasky, J. Hauxwell, M.L. Cole, J. Cebrián, and K.D. Kroeger. 2000. Operationalizing sustainability: Management and risk assessment of land-derived nitrogen loads to estuaries. Ecological Applications 10: 1006-1023.

Wang, J., and Z. Deng. 2019. Modeling and predicting fecal coliform bacteria levels in oyster harvest waters along the Louisiana Gulf Coast. Ecological Indicators 101: 212-220. 